\title{
THE IMPACT OF EXCHANGE RATES ON VIETNAM-CHINA BILATERAL TRADE
}

\author{
Tuan Pham Anh, ${ }^{1}$ Ha Thi Tran, ${ }^{2} \&$ Nguyen Manh Hung ${ }^{3}$ \\ Corresponding author ${ }^{1}$ \\ 1,2 Vietnam Academy of Social Sciences, Hanoi, Vietnam \\ ${ }^{3}$ Ho Chi Minh National Academy of Politics, Hanoi, Vietnam \\ (tuanpa.iwep@vass.gov.vn, thienha1111@gmail.com, hungmng@gmail.com) \\ DOI: https://doi.org/10.22452/jati.vol24no1.4
}

\begin{abstract}
Using autoregressive distributed lag (ARDL) methodology with both aggregate and disaggregate data, the purpose of this study is to examine the effects of the VND/CNY currency exchange rate (including exchange rate level and volatility) on trade flows between Vietnam and China. In the disaggregate models, the long-run results indicate that nine import commodities (accounting for approximately $28.67 \%$ of the total import value) are sensitive to changes in the real exchange rate level, and nine export commodities (accounting for approximately $39.15 \%$ of the total export value) also respond to changes in the exchange rate level. Most of the unaffected commodities are raw, intermediate, and simply processed products (the biggest components in total import value). The study also finds that export commodities are more sensitive to exchange rate volatility than import commodities. In addition, the results of the aggregate model indicate that there is no statistical evidence of any linkage between the exchange rate and trade (exports and imports). In other words, the exchange rate is unlikely to be an effective tool to improve the trade balance between Vietnam and China. This study contributes towards the empirical argument for effective coordination between the monetary and trade policy of Vietnam.
\end{abstract}

Keywords: trade; deficit, exchange rate, import, export, China, Vietnam, autoregressive distributed lag

\section{Background}

China has become the biggest trading partner of Vietnam since 2010. Imports from China only accounted for $8.9 \%$ of total imports to Vietnam in 2002 but increased to 23.3\% in 2011 and 28.7\% in 2016 (GSO, 2017). Whereas exports to China steadily contributed around $10 \%$ of the total exports for the same period. 
During 2000-2015, Vietnam registered a surplus in trading with China for the first few years, but the balance turned to a persistent deficit since 2002 with the value of the imports regularly exceeding twice or three times the total value of exports (see Figure 1). As of 2015, imports from China to Vietnam amounted to 49.3 billion USD and exports were 17.14 billion USD leading the trade deficit to reach a record of 32 billion USD (GSO, 2017).

Figure 1: Total Exports, Total Imports and Trade Balance between Vietnam-China

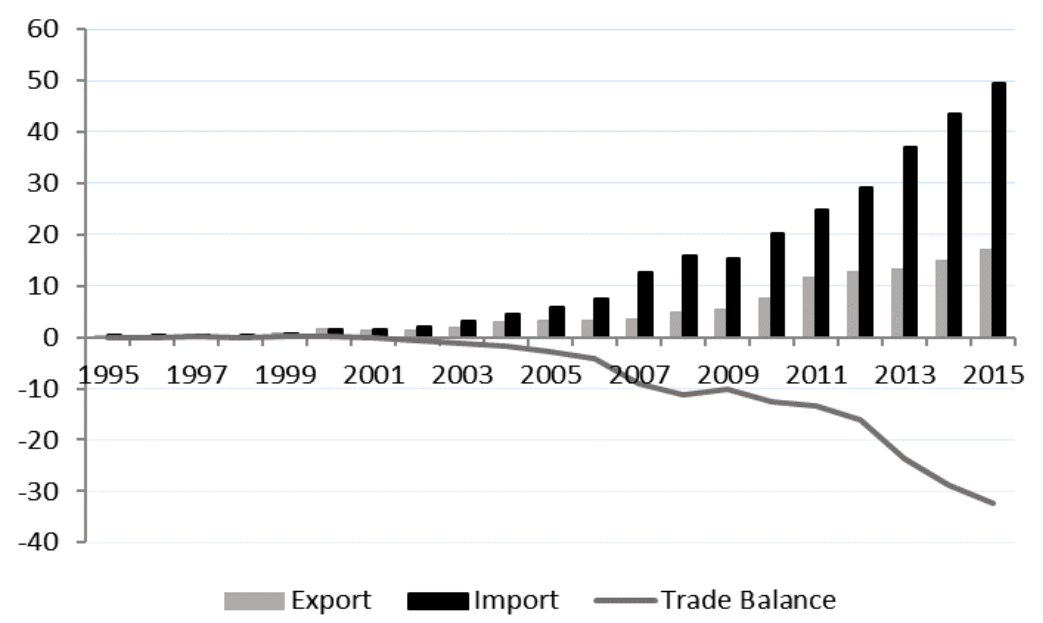

Source: Author's calculation from database of General Statistics Office Vietnam

The composition of Vietnam's imports from China has remained unchanged during the last decade, primarily consists of machinery, equipment and spare parts, processed products from raw materials, textiles, iron and steel, etc. Whereas, Vietnam's exports to China have been mainly resource-consuming and agricultural products (GSO, 2017).

The expanding trade deficit with China has become an increasing concern for Vietnam, particularly after the Chinese Yuan (CNY) was devalued against the USD by 2.6\% in August 2015 and 1.6\% in May 2016. CIEM (2016) found that, except Singapore, Vietnam is the only country that reported a significant trade deficit with China among the ASEAN members. Therefore, it raises the question of the impact of a bilateral exchange rate on the trade value between two countries and whether Vietnam could devalue its currency to reduce the trade deficit with China.

The rest of the paper is organized as follows. The next section briefly reviews the literature evaluating the impact of the exchange rate on trade in conventional economics, and, particularly, for the case of Vietnam. The 
subsequent section presents the methodology and data used in the paper. Next, the empirical results of the estimations are investigated and discussed. The paper closes with a brief summary and some concluding remarks on the findings.

\section{Literature Review}

In economic literature, the topic of investigating the impact of the exchange rate on trade value is not new as there have been substantial empirical studies evaluating the linkage between these variables. Most of these studies focus on the impact of exchange rates on aggregate exports/imports based on the MarshallLerner condition (MLC), which requires the sum of the import and export demand price elasticities to exceed unity. Mixed conclusions have been derived from these studies as far as the effectiveness of devaluation or depreciation is concerned (Bahmani-Oskooee \& Ardalani, 2006). Baek (2013) classified these studies into three categories:

(1) studies that employed aggregate trade data between a country and the rest of the world (Bahmani-Oskooee, 1986; Felrningham, 1988; Mahdavi \& Sohrabian, 1993);

(2) studies that used disaggregate trade data at the bilateral level (Arora, Bahmani-Oskooee, \& Goswami, 2003; Bahmani-Oskooee \& Ratha, 2004; Wilson, 2001); and

(3) recent studies that used disaggregate trade data at the industry/commodity level.

Baek (2013) argued that both the first and second categories may suffer from the aggregate bias problem. More specifically, when the export and import demand functions are employed by using aggregate data, significant price elasticity of some commodities/industries in a country could be more than offset by the insignificant price elasticity of others, thereby resulting in inconsistent conclusions. To address this problem, Bahmani-Oskooee and Ardalani (2006) opened a new avenue of research by using the disaggregate data of 66 US industries to examine the impact of real depreciation of the dollar on exports and imports. They concluded that, in the long run, real depreciation of the dollar stimulates the export earnings of many US industries, whereas it has no significant impact on most importing industries.

Inheriting and developing Bahmani-Oskooee's model, Baek (2013) investigated the short-run and long-run effects of exchange rate changes on the trade flows between Korea and Japan using disaggregating industry data. The empirical findings show that Korea's exports and imports are relatively sensitive to the bilateral exchange rate in the short run, but less responsive in the long run. 
More recently, to explore the nexus between the exchange rate and trade by concentrating on Malaysian-Thailand bilateral trade flows, Aftab, Syed, \& Katper (2017) used bilateral trade data at the industry level (60 export and 62 import industries) to curb the aggregation bias. Following Bahmani-Oskooee's approach, the study found that the exchange rate has a positive and significant impact on 15 export industries for which the exchange rate coefficients are significant in 14 cases. In general, the new approach allows one to explore what sector (export vs. import) has relatively more responsibility for the lack of any significant exchange rate impacts on the trade balance (Baek, 2013).

Apart from mostly qualitative studies, there are a few quantitative studies on the nexus between the exchange rate and trade for Vietnam. In addition, these studies fall into the first or second categories with aggregate data and focus on investigating the relationship between the trade balance and the exchange rate. Lord (2002) used the ECM model to calculate the long-run and short-run exchange rate elasticity of demand for exports of Vietnam from 19902001. The regression results showed that the impact of the real exchange rate on its international competitiveness and export demand had statistical significance on the global market and in some regional markets.

T. T. T. Pham (2012) investigated the short and long-run impact of the exchange rate on the trade balance in Vietnam. By employing autoregressive distributed lag (ADRL) to explore the long-run impact, the study showed that real exchange rate depreciation improved the trade balance. At the same time, the study also demonstrated the existence of the J-curve effect in the relationship between the real exchange rate and the trade balance of Vietnam.

Hoang (2013) used a reduced-form VAR model to estimate trade balance responses to a positive shock to the real VND/USD exchange rate. The author verified the existence of the J-curve for Vietnam and that its effect lasted for 11 months.

T. H. H. Pham and Nguyen (2013) analysed the linkages among foreign direct investment, exports, and the real exchange rate in a co-integration framework. Using annual panel data for the period 1990 - 2007, the authors found that the real exchange rate affected exports through two channels: the direct effect on the relative price of goods and an indirect effect through Foreign Direct Investment (FDI).

$\mathrm{Vu}, \mathrm{Vu}$, and Nguyen (2013) employed the VECM model with industrial data at the 4-digit level to estimate the impact of the exchange rate on exports with Vietnam's key trading partners, including the United States (US), Japan, Korea, and the European Union (EU). The authors found that, in general, the impact is positively significant but that the magnitude differs according to 
specific sectors and trade partners; however, the study did not consider China among the key trading partners of Vietnam.

Phan and Jeong (2015) employed panel co-integration techniques to investigate the impact of the real exchange rate on the bilateral trade balance for the country as a whole as well as on a bilateral basis with 16 trading partners over the period 1999-2012. They concluded that Vietnam's trade balance would significantly deteriorate after a permanent devaluation.

Mai (2016) aimed to calculate the impact of the exchange rate and other factors on Vietnam seafood exports to Japan and the US market. The empirical results showed that the real VND/USD exchange rate has a positive effect on Vietnam's seafood exports to the US. In contrast, Vietnam's seafood exports were negatively affected by the VND/JPY exchange rate over the period 2004-2014.

Overall, the studies investigating the relationship between the exchange rate and trade (including exports, imports, and trade balance) for Vietnam are limited. Most of the studies only employed aggregate data for the analyses, excluding Vu et al. (2013). Regarding the findings, all the studies concluded that the real exchange rate has a positive impact on the trade balance in the long run (Lord, 2002; Mai, 2016; T. H. H. Pham \& Nguyen, 2013; T. T. T. Pham, 2012; Vu et al., 2013) with the exception of the study done by Phan and Jeong (2015). Being the only study employing disaggregate data, $\mathrm{Vu}$ et al. (2013) investigated the impact of the exchange rate on the trade relationship between Vietnam and major trading partners including the US, Japan, the EU, and Korea. However, this study did not consider China in the analysis.

In summary, there is barely any study exploring the linkage between the trade balance and the performance of the bilateral exchange rate between Vietnam and China. This study will attempt to fill the void using the ARDL approach to investigate the empirical linkage between the trade deficit, versus the bilateral exchange rate $\mathrm{VND} / \mathrm{CNY}$, and its volatility. The outcomes of the study aim to address these research questions:

(1) Is there a linkage between the trade deficit and the exchange rate between the two countries?

(2) What are the specific impacts of the adjustment in the exchange rate and its volatility on the value of each commodity group (in imports and exports)?

\section{Methodology and Models}

\section{Export and Import Model}

Following the approach formulated by Bahmani-Oskooee and Ardalani (2006), and further developed by Baek (2013), this study establishes the trade demand 
model (including both imports and exports) to examine the impact of exchange rate changes, exchange rate uncertainty, and domestic income on the imports and exports in each commodity group/industry between Vietnam and China. The models are presented as follows:

$$
\begin{aligned}
& \ln E X_{i t}^{V N}=a_{0}+a_{1} \ln I N D_{t}^{C N}+a_{2} \ln R E R_{t}+a_{3} \ln V O_{t}+\varepsilon_{t} \\
& \text { lnIM } M_{i t}^{V N}=b_{0}+b_{1} l n I N D_{t}^{V N}+b_{2} l n R E R_{t}+b_{3} l n V O_{t}+\mu_{t}
\end{aligned}
$$

In which $E X_{i t}^{V N}\left({ }^{V M N}\right)$ is the value of Vietnam's exports (imports) to (from) China; $I N D_{t}^{V N}\left(I N D_{t}^{C N}\right)$ is the industrial production index of Vietnam (China), the proxy for the real income of Vietnam (China). $R E R_{\text {it }}$ is the real exchange rate between VND (Vietnamese Dong) and CNY (Chinese Yuan), which is defined as:

$R E R=N E R \times \frac{P}{P^{*}}$

Where ${ }^{N E R}$ is the nominal exchange rate between VND and CNY, and ${ }^{P}\left(P^{*}\right)$ is the price level of Vietnam (China). ${ }^{V O_{t}}$ is the volatility of the nominal exchange rate, which is calculated as the standard deviations of all the daily exchange rates in each month. In this study, Vietnam is considered the domestic economy and China is the partner country.

\section{Testing and Estimations}

Employing an autoregressive distributed lag modelling (ARDL) approach, the study investigates both short-run and long-run linkages in co-integration analysis. Following the method proposed by Pesaran, Shin, and Smith (2001), the error-correction modelling format of equations (1) and (2) are rewritten as follows:

For exports:

$$
\begin{aligned}
& \Delta l n E X_{i t}^{V N}=a_{0}+\sum_{k=1}^{q} a_{1 k} \Delta l n E X_{i, t-k}+\sum_{k=0}^{q} a_{2 k} \Delta I N D_{t-k}^{C N}+\sum_{k=0}^{q} a_{3 k} \Delta l n R E R_{t-k}+ \\
& \sum_{k=0}^{q} a_{4 k} \Delta l n V O_{t-k}+a_{0} \operatorname{lnE} X_{i, t-1}+a_{1} \operatorname{lnIND_{t-1}^{CN}}+a_{2} \operatorname{lnRER} R_{t-1}+a_{3} \operatorname{lnVO} O_{t-1}+\varepsilon_{t}
\end{aligned}
$$

For imports:

$$
\begin{aligned}
& \Delta l n I M_{i t}^{V N}=b_{0}+\sum_{k=1}^{q} b_{1 k} \Delta l n I M_{i, t-k}+\sum_{k=0}^{q} b_{2 k} \Delta I N D_{t-k}^{V N}+\sum_{k=0}^{q} b_{3 k} \Delta l n R E R_{t-k}+ \\
& \sum_{k=0}^{q} b_{4 k} \Delta l n V O_{t-k}+b_{0} l n I M_{i, t-1}+b_{1} l n I N D_{t-1}^{V N}+b_{2} l n R E R_{t-1}+b_{3} l n V O_{t-1}+v_{t}
\end{aligned}
$$


In which, $q$ is lag order and $\Delta_{\text {is }}$ the difference operator. The long-run effects are denoted as the estimated coefficients of $\ln E X_{i, t-1}, \ln I M_{i, t-1}, \ln I N D_{t-1}, \ln R E R_{t-1}$, $\operatorname{lnVO}_{t-1}$, in each equation. The coefficients of the summation signs $(\Sigma)$ showed the short-run effects of the exchange rate changes on exports and imports.

Pesaran et al. (2001) proposed a new approach for testing the existence of a relationship between the variables in levels that does not require all the variables being stationary time series. The null hypothesis of the existence of a long-run relationship is defined by: $H_{0:} a_{0}=a_{1}=a_{2}=a_{3}=0$ in equation (3) or $H_{0}$ : $b_{0}=b_{1}=b_{2}=b_{3}=0$ in equation (4). This test used the standard F-test with new sets of asymptotic critical values being specifically tabulated. The upper critical value assumes that all variables are $I(1)$ or nonstationary, while the lower critical value is tabulated by assuming that all the variables are $I(0)$ or stationary. If the computed F-statistic is greater than the upper bound of the critical value, then $H_{0}$ could be rejected.

In short, the technique used in this study is presented in the following steps:

1. Ensure that no variable used in the models is $I(2)$, as such data will invalidate the methodology.

2. Determine the appropriate lag structure for the "unrestricted" errorcorrection model (ECM), which is a particular type of ARDL model.

3. Perform a "Bounds Test" to see if there is evidence of a long-run relationship between the variables.

4. If the outcome of the previous step is positive, estimate a long-run "levels model", as well as a separated "restricted" ECM.

5. Use the results of the models estimated in the previous step to measure the short-run dynamic effects, and the long-run equilibrating relationship between the variables.

\section{Variables and Data Sources}

The bilateral export and import value are the main dependent variables in this study. For ARDL estimation, the data of total exports (to China) and imports (from China), in general, and some key industries/commodities, in particular, are collected from the General Custom Agency of Vietnam. The statistics of the imports and exports in Vietnam are classified according to the current export and import tariff schedules, which were compiled based on the Harmonized system (HS 2012 version). In detail, the import data consist of 33 groups of commodities, 
which account for $92 \%$ of the total import value. The export data consist of 32 groups of commodities covering $90 \%$ of the total export value. For the exchange rate variables, the data of different frequencies are obtained from the database of the State Bank of Vietnam. As the monthly frequency data for real income are unavailable, this study uses the industrial production index as the equivalent proxy. The data for the industrial production index for both countries are collected from the database of the Asia Regional Integration Centre (ADB). All the variables are seasonally adjusted and transformed into natural logarithms. Finally, the dataset contains 96 monthly observations ranging from January 2009 to December 2016.

\section{Empirical Results}

\section{Stationary Test}

According to Pesaran et al. (2001), bounds testing approaches to investigate the cointegration relationship between the variables in levels could be used with a mixture of $I(0)$ and $I(1)$ data. However, this condition is not fulfilled in the presence of an integrated stochastic trend of ${ }^{I(2)}$ (Nkoro \& Uko, 2016). To avoid such condition, the unit root test should be conducted to make sure that none of variables are $I(2)$. Therefore, we conducted a unit root test employing the Augmented Dickey-Fuller (ADF) procedure on all the variables in the model. The results of the ADF tests show that all the variables are stationary $I(0)$ or integrated of order one ${ }^{I(1)}$ (see Table 1 and Table 2).

\section{Optimal Lag Selection}

To obtain the optimal lag structure in equations (3) and (4), we employ the Akaike Information Criterion (AIC) procedure and Lagrange multiplier (LM) statistics for testing the hypothesis of no serial correlation (see Table 1 and Table 2). The results indicate that the null hypothesis cannot be rejected at the $5 \%$ level for all models at the maximum of six (6) lags. Therefore, it is reasonable to examine the existence of a cointegrating relationship among the variables in each model. 
Table 1: Diagnostic Tests of Import Equation

\begin{tabular}{|c|c|c|c|c|c|c|c|c|}
\hline \multirow[b]{2}{*}{ Products } & \multicolumn{3}{|c|}{ Cointegration Test } & \multicolumn{2}{|c|}{ CUSUM Test } & \multicolumn{3}{|c|}{ LM Test } \\
\hline & $\begin{array}{l}\text { F_statisti } \\
\text { c }\end{array}$ & $\mathrm{EC}(\mathrm{t}-1)$ & & $\begin{array}{l}\text { CUSU } \\
\mathbf{M}\end{array}$ & $\begin{array}{l}\text { CUSUMS } \\
\mathrm{Q}\end{array}$ & $\mathbf{F}$ & P_value & Share (\%) \\
\hline Rubber & 5.08 & $-0.28^{* * *}$ & -0.08 & US & US & 0.00 & 0.98 & 0.10 \\
\hline Plastic materials & 2.79 & -0.0661 & -0.09 & US & US & 3.28 & 0.07 & 1.32 \\
\hline Electrical wire and cable & 16.65 & $-0.83^{* * *}$ & -0.10 & US & US & 1.39 & 0.24 & 1.05 \\
\hline Pharmaceutical & 4.81 & $-0.46^{* * *}$ & -0.11 & S & $S$ & 0.58 & 0.45 & 0.09 \\
\hline Paper & 1.67 & $-0.18^{* *}$ & -0.08 & US & $S$ & 0.88 & 0.35 & 0.63 \\
\hline $\begin{array}{l}\text { Wood and wooden } \\
\text { products }\end{array}$ & 5.59 & $-0.54^{* * *}$ & -0.12 & US & $\mathrm{s}$ & 3.39 & 0.07 & 0.57 \\
\hline Chemicals & 2.35 & -0.18 & -0.13 & US & US & 0.05 & 0.83 & 2.02 \\
\hline Liquefied petroleum gas & 2.39 & $-0.38^{* * *}$ & -0.13 & US & $\mathrm{S}$ & 2.51 & 0.12 & 0.40 \\
\hline Other base metals & 7.12 & $-0.41^{* * *}$ & -0.09 & $S$ & $S$ & 0.19 & 0.66 & 3.04 \\
\hline $\begin{array}{l}\text { Parts and accessories for } \\
\text { motor }\end{array}$ & 1.73 & -0.09 & -0.08 & $\mathrm{~s}$ & $S$ & 1.15 & 0.29 & 1.35 \\
\hline $\begin{array}{l}\text { Machinery, instrument, } \\
\text { accessory }\end{array}$ & 2.01 & $-0.29^{* * *}$ & -0.11 & $S$ & $S$ & 1.15 & 0.29 & 18.58 \\
\hline $\begin{array}{l}\text { Computers, Electronical } \\
\text { products \& parts }\end{array}$ & 7.02 & $-0.35^{* * *}$ & -0.08 & US & $S$ & 2.48 & 0.12 & 11.85 \\
\hline Pharmaceutical products & 4.10 & $-0.34^{* * *}$ & -0.10 & $S$ & US & 0.53 & 0.47 & 0.47 \\
\hline $\begin{array}{l}\text { Auxiliary materials for } \\
\text { textile, garment, leather, } \\
\text { footwear }\end{array}$ & 4.15 & $-0.15^{* * *}$ & -0.06 & US & $S$ & 0.46 & 0.50 & 3.75 \\
\hline $\begin{array}{l}\text { Auxiliary materials for } \\
\text { cigarettes }\end{array}$ & 2.70 & -0.11 & -0.09 & $\mathrm{~S}$ & US & 0.48 & 0.49 & 0.16 \\
\hline Motor vehicles, assembled & 0.93 & -0.07 & -0.07 & US & $S$ & 0.23 & 0.63 & 0.85 \\
\hline Fertilizers & 7.22 & $-0.48^{* * * *}$ & -0.10 & US & $S$ & 1.82 & 0.18 & 0.94 \\
\hline $\begin{array}{l}\text { Other means of transport } \\
\text { and equipment }\end{array}$ & 15.03 & $-0.76^{* * *}$ & -0.10 & $S$ & $S$ & 2.80 & 0.10 & 0.26 \\
\hline $\begin{array}{l}\text { Fresh and processed } \\
\text { vegetables and fruit }\end{array}$ & 4.23 & $-0.40^{* * *}$ & -0.12 & $S$ & $S$ & 0.61 & 0.44 & 0.44 \\
\hline Iron, Steel & 8.90 & $-0.56^{* * *}$ & -0.10 & $S$ & $S$ & 2.08 & 0.15 & 8.91 \\
\hline Articles of plastics & 2.61 & $-0.35^{* * *}$ & -0.11 & $S$ & $S$ & 0.30 & 0.58 & 2.99 \\
\hline Articles of rubber & 5.23 & $-0.48^{* * *}$ & -0.13 & $S$ & $S$ & 0.96 & 0.33 & 0.44 \\
\hline Paper products & 21.82 & $-0.86^{* * *}$ & -0.09 & $S$ & $S$ & 0.13 & 0.72 & 0.48 \\
\hline Chemical products & 11.41 & $-0.73^{* * *}$ & -0.11 & $S$ & US & 1.25 & 0.27 & 1.73 \\
\hline Other base metal products & 11.71 & $-0.76^{* * *}$ & -0.12 & $S$ & S & 0.48 & 0.49 & 0.61 \\
\hline Articles of iron and steel & 3.62 & $-0.34^{* * *}$ & -0.09 & US & $S$ & 0.44 & 0.51 & 2.13 \\
\hline $\begin{array}{l}\text { Animal fodder and } \\
\text { materials }\end{array}$ & 6.26 & $-0.38^{* * *}$ & -0.08 & $S$ & $S$ & 0.82 & 0.37 & 0.53 \\
\hline Fishery products & 5.85 & $-0.58^{* * *}$ & -0.13 & US & $S$ & 0.13 & 0.72 & 0.14 \\
\hline Insecticides and materials & 12.41 & $-0.67^{* * *}$ & -0.10 & $S$ & US & 0.22 & 0.64 & 0.71 \\
\hline Textile fabrics & 1.33 & -0.11 & -0.08 & US & US & 0.00 & 0.97 & 10.91 \\
\hline Petroleum oil, refined & 2.86 & $-0.34^{* * *}$ & -0.13 & $\mathrm{~S}$ & $S$ & 1.29 & 0.26 & 0.90 \\
\hline Fibres, not spun & 4.33 & $-0.16^{* *}$ & -0.07 & US & $S$ & 0.99 & 0.32 & 1.40 \\
\hline Telephones and their parts & 3.80 & $-0.28^{* * *}$ & -0.08 & $S$ & US & 1.05 & 0.31 & 12.30 \\
\hline
\end{tabular}

Note. The standard errors for the regression coefficients are in parentheses; ${ }^{* * *},{ }^{* *}$, and ${ }^{*}$ indicate the $1 \%, 5 \%$, and $10 \%$ significance levels, respectively; Share (\%) is the contribution in total imports. 
Table 2: Diagnostics test of export models

\begin{tabular}{|c|c|c|c|c|c|c|c|c|}
\hline \multirow[b]{2}{*}{ Products } & \multicolumn{3}{|c|}{ Cointegration Test } & \multicolumn{2}{|c|}{ CUSUM Test } & \multicolumn{3}{|c|}{ LM Test } \\
\hline & F_statistic & $E C(t-1)$ & & CUSUM & CUSUMSQ & $\mathbf{F}$ & P_value & $\begin{array}{l}\text { Share } \\
(\%)\end{array}$ \\
\hline $\begin{array}{l}\text { Sweets, cookies and cereal } \\
\text { preparations }\end{array}$ & 6.02 & $-0.30^{* * *}$ & -0.08 & S & US & 0.44 & 0.51 & 0.35 \\
\hline Plastic materials & 4.77 & $-0.36^{* * *}$ & -0.08 & S & S & 0.37 & 0.55 & 0.46 \\
\hline Coffee & 5.26 & $-0.47^{* * *}$ & -0.11 & $\mathrm{~S}$ & $\mathrm{~S}$ & 0.92 & 0.34 & 0.49 \\
\hline Tea & 3.95 & $-0.31^{* *}$ & -0.10 & US & US & 0.12 & 0.73 & 0.12 \\
\hline Rubber & 1.68 & $-0.19^{*}$ & -0.10 & US & US & 0.96 & 0.33 & 4.52 \\
\hline Electrical wire and cable & 2.17 & $-0.16^{* *}$ & -0.06 & US & US & 0.72 & 0.40 & 1.61 \\
\hline Textile, sewing products & 2.75 & $-0.22^{* *}$ & -0.09 & US & US & 2.03 & 0.16 & 3.76 \\
\hline Telephones and their parts & 1.80 & -0.09 & -0.10 & S & S & 0.40 & 0.53 & 3.64 \\
\hline Crude oil & 23.33 & $-0.97^{* *}$ & -0.10 & $S$ & $S$ & 0.14 & 0.71 & 5.95 \\
\hline Footwear & 1.18 & -0.02 & -0.12 & S & US & 1.60 & 0.21 & 4.12 \\
\hline Paper and paper products & 2.58 & $-0.18^{*}$ & -0.09 & US & US & 0.34 & 0.56 & 0.02 \\
\hline Wood and wooden products & 7.99 & $-0.47^{* * *}$ & -0.10 & US & S & 0.09 & 0.76 & 4.64 \\
\hline Pottery and glassware & 7.22 & $-0.51^{* * *}$ & -0.10 & S & S & 0.77 & 0.38 & 0.02 \\
\hline Chemicals & 1.31 & $-0.22 *$ & -0.12 & S & $S$ & 0.38 & 0.54 & 0.45 \\
\hline Cashew nut & 15.13 & $-0.78^{* * *}$ & -0.10 & S & S & 0.56 & 0.46 & 1.92 \\
\hline Seafood & 10.54 & $-0.60^{* * *}$ & -0.10 & S & US & 1.55 & 0.22 & 3.12 \\
\hline $\begin{array}{l}\text { Other base metals and } \\
\text { products }\end{array}$ & 2.72 & $-0.43^{* * *}$ & -0.14 & S & S & 0.01 & 0.91 & 0.31 \\
\hline Cameras and their parts & 1.23 & $-0.09^{*}$ & -0.05 & S & US & 1.74 & 0.19 & 7.56 \\
\hline $\begin{array}{l}\text { Machinery, instrument, } \\
\text { accessory }\end{array}$ & 5.72 & $-0.37^{* * *}$ & -0.09 & $S$ & US & 0.21 & 0.65 & 5.06 \\
\hline Computers and their parts & 1.96 & $-0.19^{* *}$ & -0.08 & S & $S$ & 1.13 & 0.29 & 18.47 \\
\hline $\begin{array}{l}\text { Means of transport and } \\
\text { equipment }\end{array}$ & 2.81 & $-0.40^{* * *}$ & -0.15 & US & US & 1.22 & 0.27 & 0.94 \\
\hline Ores and other minerals & 3.77 & $-0.46^{* * *}$ & -0.13 & S & US & 2.52 & 0.12 & 0.29 \\
\hline $\begin{array}{l}\text { Fresh and processed } \\
\text { vegetables and fruit }\end{array}$ & 1.79 & -0.12 & -0.08 & US & US & 0.14 & 0.71 & 7.91 \\
\hline Articles of plastics & 4.27 & $-0.34^{* * *}$ & -0.11 & S & US & 0.00 & 0.97 & 0.21 \\
\hline Articles of rubber & 1.88 & $-0.23^{*}$ & -0.11 & US & $S$ & 0.00 & 0.95 & 0.29 \\
\hline Chemical products & 3.64 & $-0.36^{* * *}$ & -0.10 & US & US & 0.88 & 0.35 & 0.36 \\
\hline Cassava and cassava products & 6.35 & $-0.40^{* * *}$ & -0.09 & S & S & 0.03 & 0.86 & 3.95 \\
\hline Iron, Steel & 5.45 & $-0.35^{* * *}$ & -0.08 & US & S & 1.50 & 0.22 & 0.03 \\
\hline Articles of iron and steel & 7.23 & $-0.72^{* * *}$ & -0.14 & S & US & 0.15 & 0.70 & 0.22 \\
\hline $\begin{array}{l}\text { Bags, pockets, wallets, } \\
\text { suitcases, hats and umbrellas }\end{array}$ & 1.09 & -0.11 & -0.11 & S & $S$ & 0.27 & 0.61 & 0.70 \\
\hline Glass and glassware & 1.65 & $-0.23^{* *}$ & -0.10 & S & S & 0.16 & 0.69 & 0.30 \\
\hline Petroleum oil, refined & 2.73 & $-0.21^{* * *}$ & -0.08 & US & US & 0.39 & 0.53 & 0.78 \\
\hline Fibres, not spun & 2.98 & $-0.39^{* * *}$ & -0.12 & $S$ & $S$ & 0.04 & 0.84 & 7.51 \\
\hline
\end{tabular}

Note. The standard errors for the regression coefficients are in parentheses; ${ }^{* * *},{ }^{* *}$, and * indicate the $1 \%, 5 \%$, and $10 \%$ significance levels, respectively; Share $(\%)$ is the contribution in total exports. 


\section{Bounds Testing for Cointegration}

Following the ARDL technique used by Pesaran et al. (2001), we conduct the Ftest with the null hypothesis of no cointegration $H_{0}: a_{0}=a_{1}=a_{2}=a_{3}=0$ in equation (3) or $H_{0}: b_{0}=b_{1}=b_{2}=b_{3}=0$ in equation (4). It should be noted that BahmaniOskooee and Ardalani (2006) indicated that the F-test would be sensitive to the number of lags imposed on each first differenced variable. For this reason, following Banerjee, Dolado, and Mestre (1998), in this study, a negative and significant error-correction term $\left(E C_{\mathrm{t}-1}\right)$ is used as another criterion to determine the existence of the long-run relationship among the variables. The results (see Table 1) show that the F-statistic in 21/33 import models is higher than the critical value of 3.77; however, the coefficient of the error-correction term of the import models is negative and statistically significant for $27 / 33$ models. Therefore, the existence of a long-run relationship could be found in those 27/33 import commodities. For the export models, the calculated F-statistic is found to be higher than its critical value for 15/32 commodities, and, of the remaining, 14/17 commodities are also considered to be cointegrated since their coefficients of the error-correction term are negative and significant at the $5 \%$ level. These results imply the existence of a cointegration relationship among four variables of the import and export models and allow further analysis to be performed.

\section{Results of Disaggregate Model}

Table 3 and Table 4 summarize the results of the estimated coefficients for each commodity from the import and export models. In detail, Table 5 presents the long-run coefficients of the import models for 27 commodities. The results show that there are 9 commodities (accounting for $28.67 \%$ of the total import value) where real exchange rate coefficients are significant at the $5 \%$ or $10 \%$ level.

Table 3: Summary of Import Models Estimation

\begin{tabular}{|l|c|c|c|c|c|c|}
\hline \multirow{2}{*}{ Commodities } & \multicolumn{2}{|c|}{ Exchange rate level } & \multicolumn{2}{c|}{$\begin{array}{c}\text { Exchange rate } \\
\text { volatility }\end{array}$} & \multicolumn{2}{c|}{ Income } \\
\cline { 2 - 7 } & Longrun & Shortrun & Longrun & Shortrun & Longrun & Shortrun \\
\hline Rubber & $\mathrm{N}$ & - & - & $\mathrm{N}$ & $\mathrm{N}$ & $\mathrm{N}$ \\
\hline Electrical wire and cable & - & + & $\mathrm{N}$ & $\mathrm{N}$ & + & $\mathrm{N}$ \\
\hline Pharmaceutical & - & + & $\mathrm{N}$ & $\mathrm{N}$ & $\mathrm{N}$ & + \\
\hline Paper & $\mathrm{N}$ & $\mathrm{N}$ & $\mathrm{N}$ & $\mathrm{N}$ & + & + \\
\hline Wood and wooden products & $\mathrm{N}$ & + & $\mathrm{N}$ & $\mathrm{N}$ & + & + \\
\hline Liquefied petroleum gas & - & + & $\mathrm{N}$ & $\mathrm{N}$ & - & $\mathrm{N}$ \\
\hline Other base metals & $\mathrm{N}$ & $\mathrm{N}$ & - & $\mathrm{N}$ & + & $\mathrm{N}$ \\
\hline Machinery, instrument, & $\mathrm{N}$ & $\mathrm{N}$ & $\mathrm{N}$ & $\mathrm{N}$ & + & $\mathrm{N}$ \\
\hline
\end{tabular}




\begin{tabular}{|l|c|c|c|c|c|c|}
\hline accessory & & & & & & \\
\hline $\begin{array}{l}\text { Computers, Electronic } \\
\text { products \& parts }\end{array}$ & - & + & - & + & + & $\mathrm{N}$ \\
\hline Pharmaceutical products & $\mathrm{N}$ & $\mathrm{N}$ & $\mathrm{N}$ & $\mathrm{N}$ & $\mathrm{N}$ & + \\
\hline $\begin{array}{l}\text { Auxiliary materials for } \\
\text { textile, garment, leather, } \\
\text { footwear }\end{array}$ & $\mathrm{N}$ & + & + & $\mathrm{N}$ & + & $\mathrm{N}$ \\
\hline Fertilizers & - & $\mathrm{N}$ & - & $\mathrm{N}$ & - & + \\
\hline $\begin{array}{l}\text { Other means of transport and } \\
\text { equipment }\end{array}$ & $\mathrm{N}$ & $\mathrm{N}$ & $\mathrm{N}$ & $\mathrm{N}$ & + & $\mathrm{N}$ \\
\hline $\begin{array}{l}\text { Fresh and processed } \\
\text { vegetables and fruit }\end{array}$ & $\mathrm{N}$ & - & - & + & + & $\mathrm{N}$ \\
\hline Iron, Steel & $\mathrm{N}$ & $\mathrm{N}$ & - & $\mathrm{N}$ & + & $\mathrm{N}$ \\
\hline Articles of plastics & $\mathrm{N}$ & + & $\mathrm{N}$ & $\mathrm{N}$ & + & $\mathrm{N}$ \\
\hline Articles of rubber & - & + & + & $\mathrm{N}$ & + & + \\
\hline Paper products & $\mathrm{N}$ & + & $\mathrm{N}$ & $\mathrm{N}$ & + & $\mathrm{N}$ \\
\hline Chemical products & $\mathrm{N}$ & $\mathrm{N}$ & $\mathrm{N}$ & $\mathrm{N}$ & + & $\mathrm{B}$ \\
\hline Other base metal products & $\mathrm{N}$ & - & $\mathrm{N}$ & $\mathrm{N}$ & + & $\mathrm{N}$ \\
\hline Articles of iron and steel & $\mathrm{N}$ & $\mathrm{N}$ & $\mathrm{N}$ & + & + & $\mathrm{N}$ \\
\hline Animal fodder and materials & $\mathrm{N}$ & + & $\mathrm{N}$ & $\mathrm{N}$ & $\mathrm{N}$ & - \\
\hline Fishery products & $\mathrm{N}$ & $\mathrm{N}$ & $\mathrm{N}$ & + & + & - \\
\hline Insecticides and materials & - & + & - & + & $\mathrm{N}$ & $\mathrm{N}$ \\
\hline Petroleum oil, refined & - & $\mathrm{B}$ & $\mathrm{N}$ & $\mathrm{N}$ & - & + \\
\hline Fibres, not spun & $\mathrm{N}$ & $\mathrm{B}$ & $\mathrm{N}$ & $\mathrm{N}$ & + & $\mathrm{N}$ \\
\hline Telephones and their parts & - & + & $\mathrm{N}$ & $\mathrm{N}$ & $\mathrm{N}$ & + \\
\hline
\end{tabular}

Note. (+) Positive significant coefficient; (-) Negative significant coefficient; (N) Insignificant coefficient; (B) Coefficients are positive and negative significant at various lags

These commodities include electrical wire and cable; pharmaceutical; liquefied petroleum; computers, electronical product and part; fertilizers; telephones and their parts; articles of rubber; insecticides and material; and petroleum oil, refined. The coefficients are negative in all regressions implying that the depreciation of VND would reduce the imports of these commodities. For example, the estimated coefficient for electrical wire and cable is -2.49 (statistically significant at 5\% level) implying that a real depreciation of VND would decrease the import of these products. Thus, the long-run relationship between the real exchange rate and the import value in these cases supports the conventional theory. On the other hand, the exchange rate level is found to be not statistically significant in the remaining 24/33 commodities model (mainly raw, intermediate, and simply processed products, accounting for $71.33 \%$ of the total import value) including textile fabrics; machinery, instrument, accessory; iron and steel, etc. 
Table 4: Summary of Export Models Estimation

\begin{tabular}{|c|c|c|c|c|c|c|}
\hline \multirow{2}{*}{ Products } & \multicolumn{2}{|c|}{ Exchange rate level } & \multicolumn{2}{|c|}{ Exchange rate volatility } & \multicolumn{2}{|c|}{ Income } \\
\hline & Longrun & Shortrun & Long run & Shortrun & Longrun & Shortrun \\
\hline Sweets, cookies and cereal preparations & + & - & $\mathrm{N}$ & $\mathrm{N}$ & + & $\mathrm{N}$ \\
\hline Plastic materials & $\mathrm{N}$ & $\mathrm{N}$ & $\mathrm{N}$ & $\mathrm{N}$ & + & $\mathrm{N}$ \\
\hline Coffee & $\mathrm{N}$ & $\mathrm{B}$ & $\mathrm{N}$ & $\mathrm{B}$ & $\mathrm{N}$ & $\mathrm{N}$ \\
\hline Tea & $\mathrm{N}$ & $\mathrm{N}$ & $\mathrm{N}$ & $\mathrm{N}$ & $\mathrm{N}$ & - \\
\hline Rubber & $\mathrm{N}$ & - & $\mathrm{N}$ & $\mathrm{N}$ & $\mathrm{N}$ & B \\
\hline Electrical wire and cable & - & $\mathrm{N}$ & $\mathrm{N}$ & + & + & $\mathrm{N}$ \\
\hline Textile, sewing products & $\mathrm{N}$ & $\mathrm{N}$ & - & + & + & - \\
\hline Crude oil & $\mathrm{N}$ & $\mathrm{N}$ & $\mathrm{N}$ & $\mathrm{N}$ & $\mathrm{N}$ & $\mathrm{N}$ \\
\hline Paper and paper products & $\mathrm{N}$ & $\mathrm{N}$ & $\mathrm{N}$ & + & - & $\mathrm{N}$ \\
\hline Wood and wooden products & $\mathrm{N}$ & $\mathrm{N}$ & - & + & + & - \\
\hline Pottery and glassware & $\mathrm{N}$ & $\mathrm{N}$ & $\mathrm{N}$ & $\mathrm{N}$ & $\mathrm{N}$ & - \\
\hline Chemicals & $\mathrm{N}$ & $\mathrm{N}$ & $\mathrm{N}$ & - & $\mathrm{N}$ & $\mathrm{N}$ \\
\hline Cashew nut & - & - & $\mathrm{N}$ & $\mathrm{N}$ & + & - \\
\hline Seafood & $\mathrm{N}$ & $\mathrm{N}$ & + & - & + & - \\
\hline Other base metals and products & - & $\mathrm{N}$ & $\mathrm{N}$ & $\mathrm{N}$ & $\mathrm{N}$ & $\mathrm{N}$ \\
\hline Cameras and their parts & $\mathrm{N}$ & + & $\mathrm{N}$ & $\mathrm{N}$ & + & $\mathrm{N}$ \\
\hline Machinery, instrument, accessory & + & $\mathrm{N}$ & $\mathrm{N}$ & $\mathrm{N}$ & + & - \\
\hline Computers and their parts & - & + & $\mathrm{N}$ & $\mathrm{N}$ & $\mathrm{N}$ & $\mathrm{N}$ \\
\hline Means of transport and equipment & $\mathrm{N}$ & $\mathrm{N}$ & $\mathrm{N}$ & $\mathrm{N}$ & $\mathrm{N}$ & $\mathrm{N}$ \\
\hline Ores and other minerals & $\mathrm{N}$ & $\mathrm{N}$ & $\mathrm{N}$ & $\mathrm{N}$ & $\mathrm{N}$ & $\mathrm{B}$ \\
\hline Articles of plastics & $\mathrm{N}$ & + & - & + & + & $\mathrm{N}$ \\
\hline Articles of rubber & $\mathrm{N}$ & $\mathrm{B}$ & $\mathrm{N}$ & + & $\mathrm{N}$ & $\mathrm{N}$ \\
\hline Chemical products & $\mathrm{N}$ & $\mathrm{N}$ & $\mathrm{N}$ & $\mathrm{N}$ & $\mathrm{N}$ & $\mathrm{N}$ \\
\hline Cassava and cassava products & - & $\mathrm{N}$ & - & $\mathrm{N}$ & $\mathrm{N}$ & $\mathrm{N}$ \\
\hline Iron, Steel & $\mathrm{N}$ & $\mathrm{B}$ & $\mathrm{N}$ & $\mathrm{N}$ & - & $\mathrm{N}$ \\
\hline Articles of iron and steel & - & + & $\mathrm{N}$ & $\mathrm{N}$ & + & $\mathrm{N}$ \\
\hline Glass and glassware & $\mathrm{N}$ & $\mathrm{N}$ & $\mathrm{N}$ & $\mathrm{N}$ & + & - \\
\hline Petroleum oil, refined & $\mathrm{N}$ & - & $\mathrm{N}$ & + & $\mathrm{N}$ & $\mathrm{N}$ \\
\hline Fibres, not spun & - & + & $\mathrm{N}$ & $\mathrm{N}$ & + & - \\
\hline
\end{tabular}

Note. (+) Positive significant coefficient; (-) Negative significant coefficient; (N) Insignificant coefficient; (B) Coefficients are positive and negative significant at various lags

The results of the import models indicate that the adjustment of the exchange rate level would affect a small fraction of the total import value from China. In other words, the exchange rate is likely to be an ineffective tool for reducing imports from China, particularly for intermediate goods (the biggest component in total import value). 
Table 5: Estimated Long-run Coefficients of Import Models

\begin{tabular}{|c|c|c|c|c|c|c|c|c|c|c|}
\hline \multirow{2}{*}{$\frac{\text { Products }}{\text { Rubber }}$} & \multicolumn{2}{|c|}{ InRER } & \multicolumn{2}{|c|}{$\operatorname{lnVO}$} & \multicolumn{2}{|c|}{ lnIND (Vietnam) } & \multicolumn{2}{|c|}{ Constant } & \multirow{2}{*}{$\frac{\text { Obs }}{90}$} & \multirow{2}{*}{$\frac{\text { R-squared }}{0.38}$} \\
\hline & 3.47 & $(2.60)$ & $-0.23^{*}$ & $(0.12)$ & 1.07 & $(0.88)$ & -6.63 & $(6.24)$ & & \\
\hline $\begin{array}{l}\text { Electrical wire and } \\
\text { cable }\end{array}$ & $-2.49^{* *}$ & $(1.03)$ & -0.01 & $(0.05)$ & $1.76^{* * *}$ & $(0.38)$ & $17.54^{* *}$ & $(8.22)$ & 90 & 0.45 \\
\hline Pharmaceutical & $-1.95^{*}$ & $(1.10)$ & -0.05 & $(0.05)$ & 0.32 & $(0.41)$ & $10.18^{*}$ & $(5.12)$ & 90 & 0.46 \\
\hline Paper & -3.09 & $(2.34)$ & -0.04 & $(0.09)$ & $2.39^{* *}$ & $(0.89)$ & 4.02 & $(3.56)$ & 90 & 0.50 \\
\hline $\begin{array}{l}\text { Wood and wooden } \\
\text { products }\end{array}$ & -0.46 & $(0.62)$ & -0.03 & $(0.03)$ & $0.99^{* * *}$ & $(0.23)$ & 4.71 & $(3.14)$ & 90 & 0.55 \\
\hline $\begin{array}{l}\text { Liquefied petroleum } \\
\text { gas }\end{array}$ & $-3.61^{* *}$ & $(1.54)$ & -0.01 & $(0.07)$ & $-1.52^{* * *}$ & $(0.55)$ & $17.23^{* *}$ & $(8.31)$ & 89 & 0.41 \\
\hline Other base metals & 0.38 & $(1.21)$ & $-0.13^{* *}$ & $(0.06)$ & $3.65^{* * *}$ & $(0.46)$ & -3.83 & $(4.73)$ & 90 & 0.34 \\
\hline $\begin{array}{l}\text { Machinery, } \\
\text { instrument, accessory }\end{array}$ & -0.27 & $(1.00)$ & 0.01 & $(0.04)$ & $1.49^{* * *}$ & $(0.37)$ & 2.46 & $(2.83)$ & 90 & 0.43 \\
\hline $\begin{array}{l}\text { Computers, } \\
\text { Electronic products \& } \\
\text { parts }\end{array}$ & $-4.46^{* * *}$ & $(0.79)$ & $-0.14^{* *}$ & $(0.07)$ & $0.97^{* * *}$ & $(0.30)$ & $15.21^{* * *}$ & $(3.58)$ & 90 & 0.68 \\
\hline $\begin{array}{l}\text { Pharmaceutical } \\
\text { products }\end{array}$ & -2.14 & $(2.11)$ & -0.19 & $(0.14)$ & 1.34 & $(0.82)$ & 6.92 & $(6.46)$ & 90 & 0.45 \\
\hline $\begin{array}{l}\text { Auxiliary materials } \\
\text { for textile, garment, } \\
\text { leather, footwear }\end{array}$ & 2.74 & $(5.63)$ & $0.52^{*}$ & $(0.30)$ & $3.59^{* *}$ & $(1.80)$ & -4.22 & $(7.01)$ & 90 & 0.31 \\
\hline Fertilizers & $-4.13^{* *}$ & $(1.75)$ & $-0.14^{*}$ & $(0.08)$ & $-1.64^{* *}$ & $(0.67)$ & $24.69^{* * *}$ & $(9.33)$ & 90 & 0.40 \\
\hline $\begin{array}{l}\text { Other means of } \\
\text { transport and } \\
\text { equipment }\end{array}$ & 2.03 & $(2.77)$ & -0.01 & $(0.12)$ & $3.59^{* * *}$ & $(1.05)$ & -18.96 & (19.85) & 89 & 0.42 \\
\hline $\begin{array}{l}\text { Fresh and processed } \\
\text { vegetables and fruit }\end{array}$ & 0.48 & $(0.79)$ & $-0.13^{*}$ & $(0.07)$ & $0.54^{*}$ & $(0.30)$ & 1.46 & $(2.93)$ & 89 & 0.49 \\
\hline Iron, Steel & 0.27 & $(1.14)$ & $-0.12^{* *}$ & $(0.05)$ & $2.55^{* * *}$ & $(0.44)$ & -0.98 & $(5.94)$ & 90 & 0.40 \\
\hline Articles of plastics & -0.24 & $(0.87)$ & -0.01 & $(0.04)$ & $2.76^{* * *}$ & $(0.32)$ & -0.11 & $(2.80)$ & 90 & 0.48 \\
\hline Articles of rubber & $-2.57^{* * *}$ & $(0.72)$ & $0.07^{*}$ & $(0.04)$ & $1.61^{* * *}$ & $(0.26)$ & $10.23^{* * *}$ & $(3.87)$ & 89 & 0.59 \\
\hline Paper products & -0.38 & $(0.33)$ & -0.02 & $(0.01)$ & $1.44^{* * *}$ & $(0.12)$ & $4.77^{*}$ & $(2.72)$ & 89 & 0.52 \\
\hline Chemical products & 0.40 & $(0.45)$ & 0.00 & $(0.02)$ & $1.69^{* * *}$ & $(0.17)$ & -0.35 & $(3.06)$ & 90 & 0.58 \\
\hline $\begin{array}{l}\text { Other base metal } \\
\text { products }\end{array}$ & -0.04 & $(0.63)$ & -0.02 & $(0.03)$ & $2.54^{* * *}$ & $(0.22)$ & -1.85 & $(4.38)$ & 89 & 0.58 \\
\hline $\begin{array}{l}\text { Articles of iron and } \\
\text { steel }\end{array}$ & -1.49 & $(1.45)$ & -0.10 & $(0.09)$ & $1.29^{* *}$ & $(0.55)$ & 5.65 & $(4.78)$ & 89 & 0.36 \\
\hline $\begin{array}{l}\text { Animal fodder and } \\
\text { materials }\end{array}$ & -2.72 & $(2.10)$ & 0.07 & $(0.09)$ & 0.93 & $(0.78)$ & 10.00 & $(7.87)$ & 90 & 0.33 \\
\hline Fishery products & -0.56 & $(1.92)$ & -0.15 & $(0.12)$ & $3.58^{* * *}$ & $(0.74)$ & -2.71 & $(10.49)$ & 89 & 0.47 \\
\hline $\begin{array}{l}\text { Insecticides and } \\
\text { materials }\end{array}$ & $-3.08^{* * *}$ & $(0.80)$ & $-0.17^{*}$ & $(0.10)$ & -0.16 & $(0.32)$ & $23.97^{* * *}$ & $(5.89)$ & 89 & 0.46 \\
\hline Petroleum oil, refined & $-5.65^{* *}$ & $(2.53)$ & 0.13 & $(0.11)$ & $-3.49^{* * *}$ & $(1.02)$ & $24.14^{* *}$ & $(9.59)$ & 90 & 0.57 \\
\hline Fibres, not spun & 1.84 & $(2.83)$ & -0.16 & $(0.11)$ & $2.08^{* * *}$ & $(0.76)$ & -2.15 & $(3.49)$ & 90 & 0.53 \\
\hline $\begin{array}{l}\text { Telephones and their } \\
\text { parts }\end{array}$ & $-11.41^{* *}$ & $(5.16)$ & 0.04 & $(0.07)$ & 0.76 & $(0.66)$ & $27.31^{* *}$ & (10.65) & 61 & 0.39 \\
\hline
\end{tabular}

Note. The standard errors for the regression coefficients are in parentheses; ${ }^{* *}, * *$, and ${ }^{*}$ indicate the $1 \%, 5 \%$, and $10 \%$ significance levels, respectively 
For export models (see Table 6), the real exchange rate is found to be statistically significant at $10 \%$ in $9 / 32$ commodities in the long-run (approximately $39.146 \%$ of the total export value), including sweets, cookies and cereal preparations; electrical wire and cable; cashew nut; other base metals products; machinery, instrument, accessory; computers and their parts; cassava and cassava product; articles of iron and steel and fibres, not spun. The estimated coefficients are significantly positive for $2 / 32$ commodities, implying that the export of these commodities would increase when VND depreciates. Therefore, the results from the export models indicate that, in the long-run, Vietnam's exports to China are more sensitive to the exchange rate than imports from China.

Table 6: Long-run Estimated Results of Export Equation

\begin{tabular}{|c|c|c|c|c|c|c|c|c|c|c|}
\hline \multirow{2}{*}{$\begin{array}{l}\text { Products } \\
\text { Sweets, cookies } \\
\text { and cereal } \\
\text { preparations }\end{array}$} & \multicolumn{2}{|c|}{ InRER } & \multicolumn{2}{|c|}{$\ln V O$} & \multicolumn{2}{|c|}{ lnIND (China) } & \multicolumn{2}{|c|}{ Constant } & \multirow{2}{*}{$\begin{array}{c}\text { Obs } \\
90\end{array}$} & \multirow{2}{*}{$\begin{array}{c}\text { R-squared } \\
0.52\end{array}$} \\
\hline & $4.21^{* *}$ & $(1.69)$ & -0.01 & $(0.05)$ & $2.88^{* * *}$ & $(0.52)$ & $-11.72^{* * *}$ & $(3.51)$ & & \\
\hline Plastic materials & -3.41 & $(3.90)$ & -0.30 & $(0.19)$ & $2.33^{*}$ & $(1.27)$ & 8.33 & (12.14) & 90 & 0.18 \\
\hline Coffee & -2.29 & $(2.62)$ & 0.24 & $(0.16)$ & 1.25 & $(0.81)$ & 9.36 & (11.74) & 90 & 0.56 \\
\hline Tea & 1.26 & $(3.40)$ & -0.15 & $(0.18)$ & 0.56 & $(1.00)$ & -1.49 & $(9.22)$ & 90 & 0.33 \\
\hline Rubber & 2.52 & $(5.12)$ & -0.10 & $(0.17)$ & -0.62 & $(1.32)$ & -0.98 & $(8.48)$ & 90 & 0.46 \\
\hline $\begin{array}{l}\text { Electrical wire and } \\
\text { cable }\end{array}$ & $-7.23^{*}$ & $(3.69)$ & -0.11 & $(0.28)$ & $2.24^{*}$ & $(1.24)$ & 8.70 & $(5.81)$ & 90 & 0.16 \\
\hline $\begin{array}{l}\text { Textile, sewing } \\
\text { products }\end{array}$ & -1.39 & $(2.35)$ & $-0.48^{*}$ & $(0.27)$ & $2.96^{* * *}$ & $(0.72)$ & 1.76 & $(4.85)$ & 90 & 0.37 \\
\hline Crude oil & -7.63 & $(6.22)$ & 0.37 & $(0.28)$ & 0.41 & $(2.03)$ & 65.10 & (55.38) & 90 & 0.52 \\
\hline $\begin{array}{l}\text { Wood and } \\
\text { wooden products }\end{array}$ & -1.82 & $(1.36)$ & $-0.21^{* *}$ & $(0.09)$ & $0.97^{* *}$ & $(0.44)$ & 10.02 & $(6.36)$ & 90 & 0.40 \\
\hline $\begin{array}{l}\text { Pottery and } \\
\text { glassware }\end{array}$ & -0.89 & $(2.36)$ & 0.03 & $(0.10)$ & 0.90 & $(0.75)$ & 3.96 & (11.11) & 90 & 0.29 \\
\hline Chemicals & 2.74 & (10.49) & 0.50 & $(0.87)$ & 3.24 & $(3.69)$ & -6.62 & (22.27) & 90 & 0.52 \\
\hline Cashew nut & $-1.89^{* *}$ & $(0.73)$ & -0.02 & $(0.03)$ & $0.72^{* * *}$ & $(0.23)$ & $16.70^{* * *}$ & $(6.06)$ & 90 & 0.53 \\
\hline Seafood & -1.18 & $(0.84)$ & $0.17^{* *}$ & $(0.07)$ & $2.10^{* * *}$ & $(0.27)$ & 5.27 & $(4.76)$ & 90 & 0.40 \\
\hline $\begin{array}{l}\text { Other base metals } \\
\text { and products }\end{array}$ & $-9.69^{*}$ & $(4.95)$ & -0.05 & $(0.12)$ & 1.01 & $(0.99)$ & 33.42 & (20.09) & 61 & 0.43 \\
\hline $\begin{array}{l}\text { Cameras and their } \\
\text { parts }\end{array}$ & -63.61 & $(41.56)$ & -0.91 & $(0.90)$ & $14.26^{* *}$ & $(6.69)$ & 41.04 & (29.94) & 61 & 0.32 \\
\hline $\begin{array}{l}\text { Machinery, } \\
\text { instrument, } \\
\text { accessory }\end{array}$ & $3.66^{* * *}$ & $(1.34)$ & 0.05 & $(0.05)$ & $3.45^{* * *}$ & $(0.40)$ & $-12.83^{* * *}$ & $(4.00)$ & 90 & 0.48 \\
\hline $\begin{array}{l}\text { Computers and } \\
\text { their parts }\end{array}$ & $-10.25^{* *}$ & $(4.20)$ & 0.05 & $(0.16)$ & 0.13 & $(1.37)$ & $17.19^{* *}$ & $(7.26)$ & 90 & 0.44 \\
\hline $\begin{array}{l}\text { Means of } \\
\text { transport and } \\
\text { equipment }\end{array}$ & -3.63 & $(3.07)$ & -0.14 & $(0.17)$ & 0.72 & $(0.99)$ & 13.81 & (12.73) & 90 & 0.41 \\
\hline $\begin{array}{l}\text { Ores and other } \\
\text { minerals }\end{array}$ & 7.00 & $(7.77)$ & 0.25 & $(0.47)$ & 1.82 & $(2.41)$ & -25.25 & (31.74) & 90 & 0.49 \\
\hline Articles of plastics & -2.36 & $(1.79)$ & $-0.28^{*}$ & $(0.14)$ & $1.13^{* *}$ & $(0.56)$ & 7.22 & $(5.31)$ & 90 & 0.44 \\
\hline Articles of rubber & -0.68 & $(3.63)$ & -0.41 & $(0.38)$ & -0.40 & $(0.99)$ & 3.84 & $(8.28)$ & 90 & 0.56 \\
\hline $\begin{array}{l}\text { Chemical } \\
\text { products }\end{array}$ & -2.27 & $(2.16)$ & -0.08 & $(0.10)$ & 0.67 & $(0.69)$ & 8.34 & $(7.78)$ & 90 & 0.28 \\
\hline $\begin{array}{l}\text { Cassava and } \\
\text { cassava products }\end{array}$ & $-3.01^{* *}$ & (1.43) & $-0.15^{* *}$ & $(0.07)$ & 0.20 & $(0.47)$ & $13.66^{* *}$ & $(5.92)$ & 90 & 0.23 \\
\hline Iron, Steel & 6.30 & $(4.58)$ & -0.09 & $(0.20)$ & $-2.69^{*}$ & $(1.46)$ & -10.01 & (14.73) & 90 & 0.40 \\
\hline
\end{tabular}




\begin{tabular}{|c|c|c|c|c|c|c|c|c|c|c|}
\hline $\begin{array}{l}\text { Articles of iron } \\
\text { and steel }\end{array}$ & $-5.60^{* * *}$ & $(0.99)$ & 0.01 & $(0.04)$ & $0.91^{* * *}$ & $(0.31)$ & $33.95^{* * *}$ & $(8.45)$ & 90 & 0.53 \\
\hline $\begin{array}{l}\text { Glass and } \\
\text { glassware }\end{array}$ & 13.88 & $(8.64)$ & -0.08 & $(0.34)$ & $4.49^{*}$ & $(2.65)$ & -28.41 & (19.17) & 90 & 0.37 \\
\hline $\begin{array}{l}\text { Petroleum oil, } \\
\text { refined }\end{array}$ & 17.18 & $(11.48)$ & -1.11 & $(0.69)$ & 2.10 & $(3.36)$ & -28.05 & $(20.02)$ & 90 & 0.43 \\
\hline Fibres, not spun & $-9.57^{* * *}$ & $(3.36)$ & -0.02 & $(0.06)$ & $2.05^{* * *}$ & $(0.46)$ & $29.14^{* *}$ & (12.05) & 61 & 0.40 \\
\hline
\end{tabular}

Note. The standard errors for the regression coefficients are in parentheses; ${ }^{* *},{ }^{* *}$, and * indicate the $1 \%, 5 \%$, and $10 \%$ significance levels, respectively

Exchange rate volatility is found to be statistically significant at the $10 \%$ level in 5/32 export commodities (accounting for $11.92 \%$ of the total import value). In addition, the signs of the coefficients are negative in most of the cases, including textile; sewing products; wood and wooden products; sea food; articles of plastics; cassava and cassava products. For the import models, the impacts from exchange rate volatility are statistically significant for $9 / 33$ commodities (accounting for $30.87 \%$ of the total import value) including rubber; other base metal products; computers, electronic products \& parts; auxiliary materials for textile, garment, leather, footwear; fertilizers; fresh and processed vegetables and fruit; iron, steel; articles of rubber; insecticides and material. The coefficients of $8 / 33$ commodities are negative significant, indicating that higher volatility of VND/CNY would lead to lower imports of these commodities. These results indicate that, in the long run, import commodities tend to be more responsive to exchange rate uncertainty than export commodities. This finding is consistent with numerous studies that found that exchange rate volatility has a negative significant impact on trade flows, as noted by Ethier (1973), P. B. Clark (1973), Baron (1976), Cushman (1986), Perée and Steinherr (1989), and P. Clark, Tamirisa, Wei, Sadikov, and Zeng (2004) among others.

The income variable is found to be positively significant at $5 \%$ or $10 \%$ in most import and export models (see Table 5 and Table 6), suggesting that an increase in the domestic income of Vietnam (China) will boost trade flows between the two countries. In 21/27 import models, income is found to be statistically significant at the $5 \%$ or $10 \%$ level (accounting for $61.24 \%$ of the total export value), indicating the existence of cointegration. On the other hand, income is found to be statistically significant at the $5 \%$ or $10 \%$ level in $16 / 32$ export models (accounting for $44.72 \%$ of the total export value). These findings are consistent with the earlier argument of the absorption approach that domestic income affects the trade balance and that fiscal policy is favourable to improve trade balance. It also supports the common argument in the literature that the income elasticity of imports exceeds that of the export demand (Bahmani-Oskooee \& Ardalani, 2006). 
Table 7 and Table 8 report the estimated results of the short-run analysis. In principle, the exchange rate level is considered to have a short-run effect on a commodity if there is at least one coefficient that is statistically significant. The short-run import coefficients of the real exchange rate are statistically significant in 17/33 import models (accounting for approximately $25.89 \%$ of the total imports), of which coefficients are positive in 12/17 models. It is noted that the exchange rate is considered to have a positive effect if there is at least one significantly positive coefficient and no coefficients that are significantly negative. A similar procedure is used to determine which commodities received negative short-run effects from the exchange rate. From the estimated results, we can conclude that real exchange rate depreciation would increase the import of these commodities in the short run: pharmaceutical; wood and wooden products; computers; electronical products and parts; electrical wire and cable; auxiliary materials for textile, garment, leather; footwear; articles of rubber; articles of plastic; paper of products; animal folder and materials; insecticides and materials; telephones and their parts, liquefied petroleum gas.

For export models, there are 12/32 commodities (accounting for $42 \%$ of the total export value) in which at least one exchange rate coefficient is statistically significant in the short run, and their signs differ for different commodities. These commodities consist of sweets, cookies and cereal preparations; coffee; rubber; cashew nut; cameras and their parts; computer and their part; articles of plastics; articles of rubber; articles of iron and steel; petroleum oil, refined; iron, steel; fibres, not spun. This finding provides the empirical evidence to conclude that short-run exports are more sensitive to the exchange rate level than imports.

Exchange rate volatility is found to be statistically significant at $5 \%$ or $10 \%$ in 5 import commodities including computers, electronic products and parts; fresh and processed vegetables; fishery products; articles of iron and steel; insecticides and materials (accounting for approximately 15\% of total imports). Whereas there are 11 export commodities (accounting for $23 \%$ of the total export value) for which exchange-rate uncertainty plays a statistically significant role in the short-run. The volatility has a positive effect on exports for 6 commodities, including electrical wire and cable; textile, sewing products; paper and paper products; wood and wooden products; articles of plastics; petroleum oil, refined. This result contradicts that of the long-run analysis, which indicates that the number of import commodities sensitive to exchange rate uncertainty is higher than that for export commodities. 
Table 7: Estimated Short-run Coefficient Import Models

\begin{tabular}{|c|c|c|c|c|c|c|c|c|c|c|c|c|c|}
\hline \multirow{3}{*}{$\begin{array}{l}\text { Products } \\
\text { Rubber }\end{array}$} & \multirow{3}{*}{$\begin{array}{l}\text { Variable } \\
\triangle \ln R E R\end{array}$} & \multicolumn{12}{|c|}{ Lag order } \\
\hline & & \multicolumn{2}{|c|}{0} & \multicolumn{2}{|c|}{1} & \multirow{2}{*}{\multicolumn{2}{|c|}{2}} & \multicolumn{2}{|c|}{3} & \multicolumn{2}{|c|}{4} & \multicolumn{2}{|c|}{5} \\
\hline & & -0.39 & (1.44) & $-4.02^{* * *}$ & $(1.49)$ & & & & & & & & \\
\hline & $\Delta \operatorname{lnIND}$ & & & & & & & & & & & & \\
\hline & $\Delta \ln \mathrm{VO}$ & & & & & & & & & & & & \\
\hline \multirow[t]{3}{*}{ Electrical wire and cable } & $\Delta \ln R E R$ & 2.15 & $(1.81)$ & $3.66^{*}$ & $(1.88)$ & & & & & & & & \\
\hline & $\Delta \operatorname{lnIND}$ & & & & & & & & & & & & \\
\hline & $\Delta \ln \mathrm{VO}$ & & & & & & & & & & & & \\
\hline \multirow[t]{3}{*}{ Pharmaceutical } & $\Delta \operatorname{lnRER}$ & 1.03 & $(1.09)$ & $3.95^{* * *}$ & $(1.11)$ & & & & & & & & \\
\hline & $\Delta \operatorname{lnIND}$ & $0.96^{*}$ & $(0.53)$ & & & & & & & & & & \\
\hline & $\Delta \operatorname{lnVO}$ & & & & & & & & & & & & \\
\hline \multirow{3}{*}{$\begin{array}{l}\text { Wood and wooden } \\
\text { products }\end{array}$} & $\Delta \ln R E R$ & $1.95^{* * *}$ & $(0.71)$ & & & & & & & & & & \\
\hline & $\Delta \ln I N D$ & $0.99^{* *}$ & $(0.47)$ & $1.06^{* *}$ & $(0.44)$ & & & & & & & & \\
\hline & $\Delta \operatorname{lnVO}$ & & & & & & & & & & & & \\
\hline \multirow[t]{3}{*}{ Liquefied petroleum gas } & $\Delta \ln R E R$ & -0.39 & $(1.23)$ & 0.69 & $(1.26)$ & -1.02 & $(1.22)$ & -0.31 & $(1.21)$ & 1.21 & $(1.19)$ & $3.43^{* * *}$ & $(1.19)$ \\
\hline & $\Delta \operatorname{lnIND}$ & & & & & & & & & & & & \\
\hline & $\Delta \operatorname{lnVO}$ & & & & & & & & & & & & \\
\hline \multirow{3}{*}{$\begin{array}{l}\text { Computers, Electronic } \\
\text { products \& parts }\end{array}$} & $\triangle \operatorname{lnRER}$ & 0.10 & $(0.64)$ & $1.29^{* *}$ & $(0.65)$ & $1.86^{* * *}$ & $(0.61)$ & $1.31^{* *}$ & $(0.63)$ & & & & \\
\hline & $\Delta \operatorname{lnIND}$ & & & & & & & & & & & & \\
\hline & $\Delta \operatorname{lnVO}$ & $0.03^{*}$ & $(0.02)$ & $0.03^{* *}$ & $(0.01)$ & & & & & & & & \\
\hline \multirow[t]{3}{*}{ Pharmaceutical products } & $\Delta \operatorname{lnRER}$ & & & & & & & & & & & & \\
\hline & $\Delta \operatorname{lnIND}$ & 1.04 & (1.09) & 0.06 & $(1.20)$ & $2.38^{* *}$ & $(0.99)$ & & & & & & \\
\hline & $\Delta \operatorname{lnVO}$ & 0.05 & $(0.03)$ & & & & & & & & & & \\
\hline \multirow{3}{*}{$\begin{array}{l}\text { Auxiliary materials for } \\
\text { textile, garment, leather, } \\
\text { footwear }\end{array}$} & $\Delta \ln R E R$ & 0.92 & $(1.53)$ & $3.22^{* *}$ & $(1.57)$ & & & & & & & & \\
\hline & $\Delta \operatorname{lnIND}$ & & & & & & & & & & & & \\
\hline & $\Delta \operatorname{lnVO}$ & & & & & & & & & & & & \\
\hline
\end{tabular}


Tuan Pham, Ha Thi Tran \& Nguyen Manh Hung

\begin{tabular}{|c|c|c|c|c|c|c|c|c|c|c|c|c|c|}
\hline \multirow[t]{3}{*}{$\begin{array}{l}\text { Fresh and processed } \\
\text { vegetables and fruit }\end{array}$} & $\triangle \ln R E R$ & $-1.41^{* *}$ & $(0.67)$ & 1.07 & $(0.69)$ & & & & & & & & \\
\hline & $\Delta \operatorname{lnIND}$ & & & & & & & & & & & & \\
\hline & $\Delta \ln \mathrm{VO}$ & $0.04^{* *}$ & $(0.02)$ & $0.02^{*}$ & $(0.01)$ & & & & & & & & \\
\hline & $\Delta \operatorname{lnIND}$ & $0.69^{*}$ & $(0.39)$ & & & & & & & & & & \\
\hline & $\Delta \operatorname{lnVO}$ & & & & & & & & & & & & \\
\hline \multirow[t]{2}{*}{ Articles of plastics } & $\triangle \ln R E R$ & 1.04 & $(0.66)$ & $1.69^{* *}$ & $(0.67)$ & $1.49^{* *}$ & $(0.67)$ & & & & & & \\
\hline & $\Delta \ln \mathrm{VO}$ & & & & & & & & & & & & \\
\hline \multirow[t]{3}{*}{ Paper product } & $\triangle \ln R E R$ & $1.04^{*}$ & $(0.61)$ & & & & & & & & & & \\
\hline & $\Delta \operatorname{lnIND}$ & & & & & & & & & & & & \\
\hline & $\Delta \ln \mathrm{VO}$ & & & & & & & & & & & & \\
\hline \multirow[t]{3}{*}{ Other base metal products } & $\triangle \ln R E R$ & 0.77 & $(0.98)$ & -0.16 & $(1.02)$ & 0.75 & $(0.99)$ & -0.26 & $(0.99)$ & $-1.67^{*}$ & $(0.97)$ & $-2.88^{* * *}$ & $(0.96)$ \\
\hline & $\Delta \operatorname{lnIND}$ & & & & & & & & & & & & \\
\hline & $\Delta \ln \mathrm{VO}$ & & & & & & & & & & & & \\
\hline \multirow{2}{*}{$\begin{array}{l}\text { Animal fodder and } \\
\text { materials }\end{array}$} & $\Delta \operatorname{lnIND}$ & -1.12 & $(1.03)$ & $-2.01^{* *}$ & $(1.01)$ & & & & & & & & \\
\hline & $\Delta \ln \mathrm{VO}$ & & & & & & & & & & & & \\
\hline \multirow[t]{3}{*}{ Fishery products } & $\triangle \ln R E R$ & & & & & & & & & & & & \\
\hline & $\Delta \operatorname{lnIND}$ & $-5.67^{* * *}$ & $(1.93)$ & -2.52 & $(1.60)$ & & & & & & & & \\
\hline & $\Delta \ln \mathrm{VO}$ & $0.08^{*}$ & $(0.05)$ & & & & & & & & & & \\
\hline \multirow[t]{3}{*}{ Insecticides and materials } & $\triangle \ln R E R$ & $2.82^{* *}$ & $(1.16)$ & 1.66 & $(1.23)$ & 1.87 & (1.19) & & & & & & \\
\hline & $\Delta \operatorname{lnIND}$ & & & & & & & & & & & & \\
\hline & $\Delta \ln \mathrm{VO}$ & $0.11^{* *}$ & $(0.05)$ & $0.11^{* *}$ & $(0.05)$ & 0.06 & $(0.04)$ & $0.08^{* *}$ & $(0.03)$ & $0.07^{* * *}$ & $(0.02)$ & & \\
\hline \multirow[t]{3}{*}{ Fibres, not spun } & $\triangle \ln R E R$ & -0.20 & $(0.71)$ & $-1.63^{* *}$ & $(0.72)$ & 0.096 & $(0.71)$ & $-1.29^{*}$ & $(0.69)$ & $1.26^{*}$ & $(0.69)$ & & \\
\hline & $\Delta \operatorname{lnIND}$ & 0.51 & $(0.36)$ & & & & & & & & & & \\
\hline & $\Delta \ln \mathrm{VO}$ & & & & & & & & & & & & \\
\hline \multirow[t]{3}{*}{ Petroleum oil, refined } & $\Delta \ln R E R$ & $3.73^{* *}$ & (1.77) & $-3.85^{* *}$ & $(1.88)$ & & & & & & & & \\
\hline & $\Delta \operatorname{lnIND}$ & & & & & & & & & & & & \\
\hline & $\Delta \ln \mathrm{VO}$ & & & & & & & & & & & & \\
\hline
\end{tabular}




\begin{tabular}{clllllllll} 
Telephones and their parts & $\Delta \operatorname{lnRER}$ & $4.89^{* *}$ & $(2.00)$ & $4.79^{* *}$ & $(1.96)$ & $5.07^{* * *}$ & $(1.84)$ & $3.07^{*}$ & $(1.82)$ \\
& $\Delta \operatorname{lnIND}$ & $1.01^{* *}$ & $(0.47)$ & & & & & & \\
& $\Delta \ln V O$ & & & & & & & & \\
\hline
\end{tabular}

Note. The standard errors for the regression coefficients are in parentheses; ${ }^{* * *}, * *$, and ${ }^{*}$ indicate the $1 \%, 5 \%$, and $10 \%$ significance levels, respectively

Table 8: Results of Short-run Coefficients of Export Models

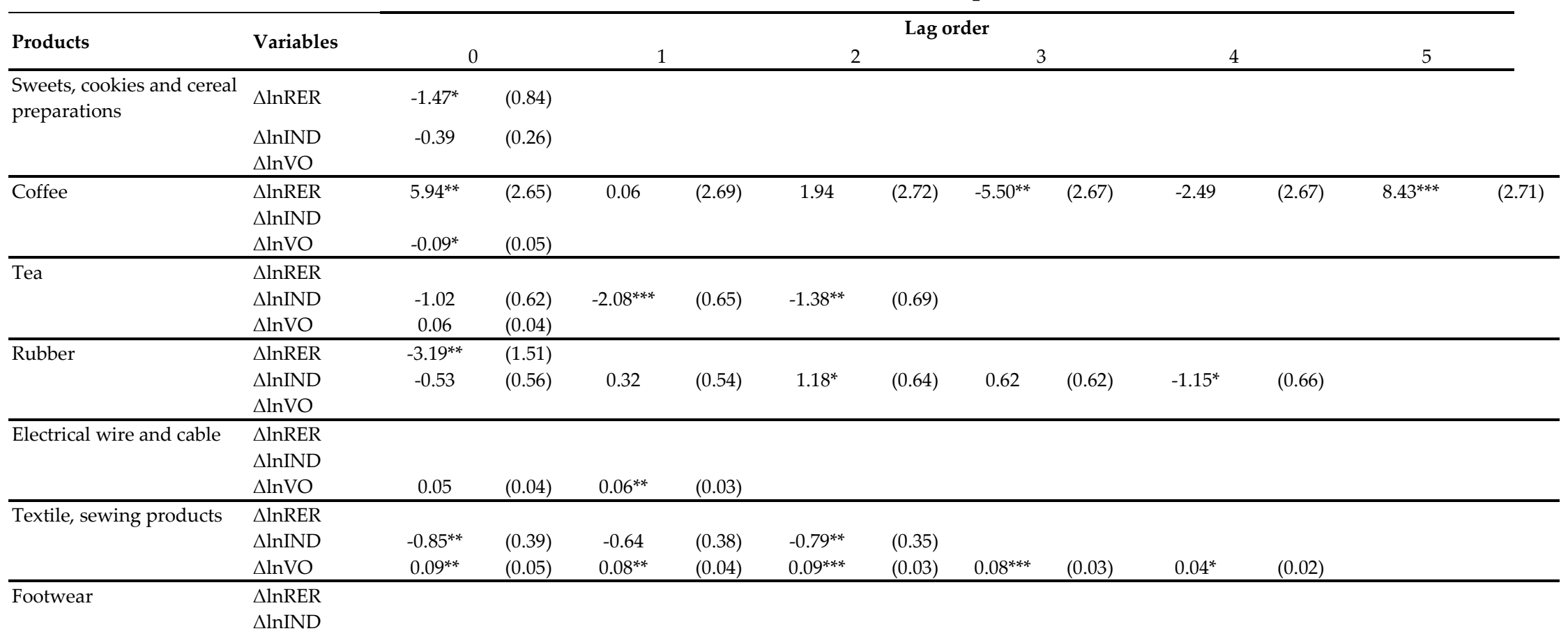


Tuan Pham, Ha Thi Tran \& Nguyen Manh Hung

\begin{tabular}{|c|c|c|c|c|c|c|c|c|c|c|c|c|c|}
\hline & $\Delta \operatorname{lnVO}$ & $-0.05^{*}$ & $(0.03)$ & & & & & & & & & & \\
\hline Paper and paper products & $\begin{array}{l}\Delta \ln R E R \\
\Delta \ln I N D \\
\Delta \ln \mathrm{VO}\end{array}$ & $0.082^{*}$ & $(0.04)$ & & & & & & & & & & \\
\hline $\begin{array}{l}\text { Wood and wooden } \\
\text { products }\end{array}$ & $\Delta \ln R E R$ & & & & & & & & & & & & \\
\hline & $\begin{array}{l}\Delta \ln I N D \\
\Delta \ln \mathrm{VO}\end{array}$ & $\begin{array}{l}-1.12^{* *} \\
0.07^{* * *}\end{array}$ & $\begin{array}{l}(0.44) \\
(0.03) \\
\end{array}$ & $-1.16^{* *}$ & $(0.47)$ & -0.66 & $(0.48)$ & & & & & & \\
\hline Chemicals & $\begin{array}{l}\Delta \ln R E R \\
\Delta \operatorname{lnIND} \\
\Delta \ln \mathrm{VO}\end{array}$ & $-0.29^{* *}$ & $(0.15)$ & $-0.28^{* * *}$ & $(0.10)$ & & & & & & & & \\
\hline Cashew nut & $\begin{array}{l}\Delta \ln R E R \\
\Delta \ln I N D \\
\Delta \ln \mathrm{VO}\end{array}$ & $\begin{array}{c}-1.23 \\
-0.59^{*}\end{array}$ & $\begin{array}{l}(1.20) \\
(0.31)\end{array}$ & -0.39 & $(1.19)$ & $-2.25^{*}$ & $(1.17)$ & 1.19 & $(1.15)$ & $-3.56^{* * *}$ & $(1.15)$ & & \\
\hline Seafood & $\begin{array}{l}\Delta \ln R E R \\
\Delta \ln I N D \\
\Delta \ln \mathrm{VO}\end{array}$ & $\begin{array}{c}-1.19^{* * *} \\
-0.06^{*}\end{array}$ & $\begin{array}{l}(0.38) \\
(0.03) \\
\end{array}$ & $\begin{array}{l}-1.52^{* * *} \\
-0.08^{* * *}\end{array}$ & $\begin{array}{l}(0.41) \\
(0.03) \\
\end{array}$ & $\begin{array}{l}-1.18^{* * *} \\
-0.05^{* *}\end{array}$ & $\begin{array}{l}(0.41) \\
(0.02)\end{array}$ & $-0.96^{* *}$ & $(0.40)$ & & & & \\
\hline Cameras and their parts & $\begin{array}{l}\Delta \ln R E R \\
\Delta \ln I N D \\
\Delta \ln \mathrm{VO}\end{array}$ & $26.28^{* * *}$ & $(6.66)$ & & & & & & & & & & \\
\hline Computers and their parts & $\begin{array}{l}\Delta \ln R E R \\
\Delta \ln I N D \\
\Delta \ln \mathrm{VO}\end{array}$ & 1.66 & $(1.56)$ & $3.39^{* *}$ & $(1.58)$ & $3.19^{* *}$ & $(1.54)$ & 2.51 & $(1.56)$ & & & & \\
\hline Articles of plastics & $\begin{array}{l}\Delta \ln R E R \\
\Delta \ln I N D \\
\Delta \ln V O\end{array}$ & $\begin{array}{c}-1.15 \\
0.05^{* *}\end{array}$ & $\begin{array}{l}(1.30) \\
(0.03)\end{array}$ & 1.53 & $(1.32)$ & $3.07^{* *}$ & $(1.34)$ & & & & & & \\
\hline Articles of rubber & $\begin{array}{l}\Delta \ln R E R \\
\Delta \operatorname{lnIND} \\
\Delta \ln \mathrm{VO}\end{array}$ & $\begin{array}{c}0.31 \\
0.14^{* *}\end{array}$ & $\begin{array}{l}(1.51) \\
(0.06)\end{array}$ & $\begin{array}{l}2.72^{*} \\
0.09\end{array}$ & $\begin{array}{l}(1.54) \\
(0.06)\end{array}$ & $\begin{array}{c}0.83 \\
0.11^{* *}\end{array}$ & $\begin{array}{l}(1.56) \\
(0.05)\end{array}$ & $\begin{array}{c}-0.59 \\
0.14^{* * *}\end{array}$ & $\begin{array}{l}(1.56) \\
(0.04)\end{array}$ & $\begin{array}{l}-4.88^{* * *} \\
0.08^{* * *}\end{array}$ & $\begin{array}{l}(1.53) \\
(0.03)\end{array}$ & $-3.94^{* *}$ & $(1.58)$ \\
\hline Iron, Steel & $\begin{array}{l}\Delta \ln R E R \\
\Delta \ln I N D \\
\Delta \ln \mathrm{VO}\end{array}$ & $-8.16^{* *}$ & $(3.63)$ & -5.89 & $(3.71)$ & -4.82 & $(3.68)$ & 0.73 & $(3.62)$ & $8.51^{* *}$ & $(3.58)$ & & \\
\hline
\end{tabular}




\begin{tabular}{|c|c|c|c|c|c|c|c|c|c|c|c|c|c|}
\hline Articles of iron and steel & $\begin{array}{l}\Delta \ln R E R \\
\Delta \ln I N D \\
\Delta \ln \mathrm{VO}\end{array}$ & $5.22^{* * *}$ & $(1.71)$ & $3.42^{*}$ & $(1.78)$ & 2.73 & $(1.68)$ & $2.76^{*}$ & $(1.63)$ & & & & \\
\hline Petroleum oil, refined & $\begin{array}{l}\Delta \ln R E R \\
\Delta \operatorname{lnIND} \\
\Delta \ln \mathrm{VO}\end{array}$ & $\begin{array}{c}0.71 \\
0.21^{* *}\end{array}$ & $\begin{array}{l}(4.92) \\
(0.09)\end{array}$ & -0.26 & $(4.93)$ & -2.01 & $(4.95)$ & 2.38 & $(4.76)$ & -2.28 & $(4.66)$ & $-14.92^{* * *}$ & $(4.66)$ \\
\hline Fibres, not spun & $\begin{array}{l}\Delta \ln R E R \\
\Delta \ln I N D \\
\Delta \ln V O\end{array}$ & $\begin{array}{c}2.68 \\
-0.71^{* *}\end{array}$ & $\begin{array}{l}(2.05) \\
(0.35)\end{array}$ & $\begin{array}{c}5.71^{* * *} \\
-0.48\end{array}$ & $\begin{array}{l}(1.96) \\
(0.32)\end{array}$ & $4.15^{* *}$ & $(1.96)$ & & & & & & \\
\hline
\end{tabular}

Note. The standard errors for the regression coefficients are in parentheses; ${ }^{* * *},{ }^{* *}$, and ${ }^{*}$ indicate the $1 \%, 5 \%$, and $10 \%$ significance levels, respectively 
Finally, we have examined the stability of the estimated coefficients of all the above models over time. We relied on the cumulative sum (CUSUM) and cumulative sum of squares (CUSUMSQ) tests, which are applied to the residuals of the ECM model in Equations (3) and (4). In the disaggregate import models, the plots of CUSUM and CUSUMSQ indicate that the long-run and short-run parameters are stable in 14/27 cases over the sample period (Table 1). Similarly, the stability test of the disaggregate export models show that there are 13 cases for which the coefficients are stable (Table 2). We denote " $\mathrm{S}$ " for a stable model and "US" for an unstable one.

\section{Results of the Aggregate Model}

Bahmani-Oskooee and Ardalani (2006) indicate that "if aggregate data are employed, significant exchange rate coefficients in some sectors could be more than offset by insignificant coefficients in other sectors". On the other hand, Brooks (1999, p. 23) find that a "disaggregate approach fail[s] to address the policy question of whether a coordinated depreciation will improve a countries bilateral trade balance".

To address the arguments concerning aggregate data, the cointegration analysis indicates that the variables are cointegrated on the import model, but not on the export model. Hence, only the long-run estimated coefficients of the import model are reported in Table 9.

Table 9: Long-run Estimated Coefficients of Import and Export Models Using Aggregate Data

\begin{tabular}{ccc}
\hline & Import Model & Export Model \\
\hline$\Delta \operatorname{lnRER}$ & -2.2350 & $(1.3564)$ \\
$\Delta \operatorname{lnVO}$ & -0.0170 & $(0.1129)$ \\
$\Delta \operatorname{lnIND}$ & $1.0077^{*}$ & $(0.5679)$ \\
Constant & $3.8012^{*}$ & $(1.9391)$ \\
R2/observation & 0.5701 & 90 \\
\hline
\end{tabular}

Note: The standard errors for the regression coefficients are in parentheses; ${ }^{* * *},{ }^{* *}$, and * indicate the $1 \%, 5 \%$, and $10 \%$ significance levels, respectively.

First, the results show that the coefficients of both the exchange rate level and exchange rate volatility are insignificant in the import model, thereby suggesting the possible existence of an aggregate bias problem. More specifically, the insignificant nexus between the exchange rate and imports from China could be the cause of the lack of a significant relationship between the bilateral 
exchange rate and exports in some but not all commodities (this is indicated by the results of the disaggregate models). Therefore, it can be concluded that the exchange rate is unlikely to be an effective policy tool to improve the trade balance between China and Vietnam.

Second, the coefficient of income elasticity is positively significant in the import model. This result is consistent with the finding of the disaggregate models, implying that Vietnam should use fiscal rather than monetary policy to adjust the trade balance with China. This finding is supported by Phan and Jeong (2015) who also argued that "Vietnam's trade balance can be improved by restructuring the economy rather than devaluating currency in the long run". Davies and Green (2010) provided an explanation for European transition countries that would be appropriate to apply in the case of Vietnam. The explanation indicates that if a country is closer to an emerging market in which changes in import prices as a consequence of exchange rate depreciation are passed through to domestic prices more rapidly, this would lead to the exchange rate having an undesirable effect on the trade balance.

For the stability test of the aggregate import model, the plot of the CUSUM statistic stays within the 5\% significance level, but the cumulative sum of squared deviates outside the area between the two $5 \%$ critical lines. Therefore, it can be concluded that the estimated coefficients are generally unstable during the period of January 2009-December 2016. In other words, the relationship among real exchange rate, income, and imports from China can be interpreted as unstable during the research period.

\section{Summary and Concluding Remarks}

In summary, this empirical study investigates the effect of the real exchange rate (including changes in exchange rate level and exchange rate volatility) on bilateral trade between Vietnam and China by using the ARDL approach with monthly aggregate and disaggregate data from January 2009 to December 2016. In the case of disaggregate data, the exchange rate level is found to be statistically significant for $9 / 33$ import commodities and 9/32 export commodities. The findings also indicate that exports are more sensitive to the real exchange rate level than imports in the long-run, whereas the volatility of the exchange rate has more impact on import commodities than export commodities. For aggregate data, the results show that there is no evidence of the linkage between the exchange rate and bilateral trade (for both exports and imports). Finally, Vietnam's income is found to have an important role in determining imports from China in both the aggregate and disaggregate data analysis. 
In conclusion, this study proves that the bilateral real exchange rate has weak linkage for both exports and imports between Vietnam and China. Furthermore, the analysis of the trade structure between two countries shows that Vietnam mostly exports primary and agricultural goods to China and imports higher value-added ones, such as machines, equipment, and intermediate goods. This result partly reflects the dependence of the Vietnam economy on the Chinese market and goods, for which exchange rate has little or no influence at all for many commodities. Therefore, to improve the trade balance and reduce the reliance on trade with China, Vietnam should further expand its international trade relationship to diversify both export and import markets, in which neighbouring ASEAN nations should be the priority targets thanks to close proximity and strong economic ties. In addition, the country should enhance its economic strength by encouraging the consumption of domestic goods and supporting the production of domestic firms to make the domestic economy less reliant on foreign markets.

\section{Acknowledgement}

This research has received funding from the European Union's Horizon 2020 research and innovation programme under grant agreement $\mathrm{N}^{\circ} 770562$ (CRISEA).

\section{References}

Aftab, M., Syed, K. B. S., \& Katper, N. A. (2017). Exchange-rate volatility and Malaysian-Thai bilateral industry trade flows. Journal of Economic Studies, 44(1), 99-114. doi: 10.1108/JES-05-2015-0091

Arora, S., Bahmani-Oskooee, M., \& Goswami, G. (2003). Bilateral J-curve between India and her trading partners. Applied Economics, 35(9), 1037-1041. doi: $10.1080 / 0003684032000102172$

Baek, J. (2013). Does the exchange rate matter to bilateral trade between Korea and Japan? Evidence from commodity trade data. Economic Modelling, 30, 856-862. doi: http://dx.doi.org/10.1016/j.econmod.2012.11.020

Bahmani-Oskooee, M. (1986). Determinants of international trade flows: The Case of developing countries. Journal of Development Economics, 20(1), 107123.

Bahmani-Oskooee, M., \& Ardalani, Z. (2006). Exchange rate sensitivity of U.S. trade flows: Evidence from industry data. Southern Economic Journal, 72(3), 542. 
Bahmani-Oskooee, M., \& Ratha, A. (2004). Dynamics of the U.S. trade with developing countries. Journal of Developing Areas, 37(2), 1-11. doi: 10.1353/jda.2004.0020

Banerjee, A., Dolado, J., \& Mestre, R. (1998). Error-correction mechanism tests for cointegration in a single-equation framework. Journal of Time Series Analysis, 19(3), 267-283.

Baron, D. (1976). Fluctuating exchange rates and the pricing of exports. Economic Inquiry, 14(3), 425-438.

Brooks, T. (1999). Currency depreciation and the trade balance: an elasticity approach and test of the Marshall-Lerner condition for bilateral trade between the US and the G-7. Doctoral dissertation, University of Wisconsin-Milwaukee, Milwaukee, United States.

CIEM. (2016). Economic dependence between Vietnam-China. Hanoi: Central Institute for Economic Management.

Clark, P., Tamirisa, N., Wei, S.-J., Sadikov, A., \& Zeng, L. (2004). Exchange rate volatility and trade flows - some new evidence. Washington, D.C.: International Monetary Fund.

Clark, P. B. (1973). Uncertainty, exchange risk, and the level of international trade. Economic Inquiry, 11(3), 302-313.

Cushman, D. O. (1986). Has exchange risk depressed international trade? The impact of third-country exchange risk. Journal of International Money and Finance, 5(3), 361-379.

Davies, H., \& Green, D. (2010). Banking on the future: The fall and rise of central banking: Princeton University Press.

Ethier, W. (1973). International trade and the forward exchange market. The American Economic Review, 63(3), 494-503.

Felrningham, B. S. (1988). Where is Australian J-curve? Bulletin of Economic Research, 40(1), 43-56. doi: 10.1111/j.1467-8586.1988.tb00253.x

GSO. (2017). Trade database. Retrieved from: http://gso.gov.vn/Default_en.aspx?tabid=491

Hoang, K. V. (2013). The effects of the real exchange rate on the trade balance: Is there a J-curve for Vietnam? A VAR approach. MPRA Paper No. 54490. Retrieved from https://mpra.ub.unimuenchen.de/54490/1/MPRA_paper_54490.pdf.

Lord, M. (2002). Vietnam's export competitiveness: Trade and macroeconomic policy linkages. MPRA Paper No. 50638. Retrieved from https://mpra.ub.uni-muenchen.de/50638/1/MPRA_paper_50638.pdf .

Mahdavi, S., \& Sohrabian, A. (1993). The exchange value of the dollar and the U.S. trade balance: An empirical investigation based on cointegradon and 
Granger causality tests. The Quarterly Review of Economics and Finance, 33(4), 343-358. doi: http://dx.doi.org/10.1016/1062-9769(93)90003-3

Mai, T. C. T. (2016). Impact of exchange rate on Vietnam seafood exports - The cases of Japan and US markets. Journal of Development and Integration (Vietnam), 26(36), 42-52.

Nkoro, E., \& Uko, A. K. (2016). Autoregressive distributed lag (ARDL) cointegration technique: Application and interpretation. Journal of Statistical and Econometric Methods, 5(4), 63-91.

Perée, E., \& Steinherr, A. (1989). Exchange rate uncertainty and foreign trade. European Economic Review, 33(6), 1241-1264.

Pesaran, M. H., Shin, Y., \& Smith, R. J. (2001). Bounds testing approaches to the analysis of level relationships. Journal of applied econometrics, 16(3), 289326.

Pham, T. H. H., \& Nguyen, T. D. (2013). Foreign direct investment, exports and real exchange rate linkages in Vietnam: Evidence from a co-integration approach. Journal of Southeast Asian Economies (JSEAE), 30(3), 250-262.

Pham, T. T. T. (2012). The impact of exchange rate fluctuation on trade balance in short and long run (Working Papers 23). Hanoi: Development and Policies Research Center (DEPOCEN).

Phan, T. H., \& Jeong, J. Y. (2015). Vietnam trade balance and exchange rate: Evidence from panel data analysis. Journal of Applied Economics $\mathcal{E}$ Business Research, 5(4), 220-232.

Vu, H. Q., Vu, P. H. D., \& Nguyen, T. T. H. (2013). Exchange rate in Vietnam during 2000-2011: Determination, misalignment, impact on exports and policy dimensions. Ha Noi: Economic Committee of Vietnam National Assembly and UNDP Vietnam.

Wilson, P. (2001). Exchange rates and the trade balance for dynamic Asian economies-Does the J-curve exist for Singapore, Malaysia, and Korea? Open Economies Review, 12(4), 389-413. doi: 10.1023/A:1017982901034 